\title{
Ajaloolisi, võrdlevaid ja korpuslingvistilisi vaateid soome-ugri keelte õppimisele ja mõistmisele
}

Tänavu täitub kolmkümmend aastat "Lähivõrdluste" esimese numbri ilmumisest. Seekordne väljaanne kannab järjekorranumbrit 25. Sarjana ilmunud eri ülikoolide toimetistest on saanud iseseisev rahvusvaheliselt eelretsenseeritav teadusajakiri. Kolmekümneaastast teekonda tähistatakse 29.10.2015 Tallinna ülikoolis toimuva konverentsiga. Oleme näinud vaeva, et juubelinumber ilmuks enne seda tähtsündmust ja Soome Rakenduslingvistika Ühingu AFinLA sügissümpoosioni. Tänu kõigile selles töös osalenutele ja kaasaaitajatele!

Seekordne "Lähivõrdlusi. Lähivertailuja" on üles ehitatud pisut teisiti kui varasemad. Väljaanne algab meenutustega algaegadest, uurimisala arenemisest, soome-ugri keelte õppimise ja omandamise lisandumisest ajakirjas käsitletavate teemade hulka, kahepoolsuse muutumisest mitmepoolsuseks, isegi kui konkreetsel üksikjuhul on sageli küsimus teatud emakeelt rääkivast isikust, kes õpib korraga üht keelt. Paljud alged olid siiski olemas juba 30 aastat tagasi, paljud tulevased muutused olid tagasi vaadates juba siis nähtavad või vähemalt aimatavad. Seda kõike meenutavad Hannu Remes, Mati Erelt ja Valve-Liivi Kingisepp. Näeme möödunud aastatest ka fotomeenutusi.

Artikleid on seekord viis. Johanna Laakso käsitleb oma artiklis soome-ugri keelte õppimist ning õpetamist ja seda eriti õppija identiteedi ja soome-ugri keelte õpetamisel lakkamatult esile tõusva mõiste erinevus seisukohalt. Keelte objektiivse ja subjektiivse sarnasuse mõjust keele õppimisele on räägitud palju. Seda, kuidas soome-ugri keelte kõnelejate armastatud müüt nende keelte erilisusest ja erandlikkusest 
mõjutab õppijate motivatsiooni ja identiteeti, on uuritud palju vähem. Samuti tuleks põhjalikumalt käsitleda edasijõudnud õppijate olukorda keelekogukonna "välisliikmetena" ja virtuaalse õppijaskonna olemust.

Pirkko Muikku-Werner jätkab juba mitmes varasemas LV numbris käsitlemist leidnud teemat, uurides lähedase sugulaskeele mõistmist ehk keelesugulusel põhinevat retseptiivset mitmekeelsust. Seekordse artikli peateema on semantiline praimimine ehk see, kuidas tähendusseosed on aluseks tundmatute sõnade tähendusest arusaamisele või selle äraarvamisele.

Pille Esloni ja Heleriin Paeoja artikkel nagu ka Jarmo H. Jantuneni ja Mare Kitsniku kirjutised põhinevad korpusuuringutel. Pille Eslon ja Heleriin Paeoja analüüsivad eesti ilukirjanduskorpuse põhjal analüütiliste ja sünteetiliste verbipaaride kasutusmustreid ja -piiranguid. Analüüsi tulemused on rakendatavad tõlkimisel, keeleõppe vahendite ja keele automaatanalüüsi arendamisel ning pakuvad uut teavet nii kirjeldavale kui ka teoreetilisele keeleuurimisele.

Jarmo H. Jantunen toob õppijakeele korpustel põhinevas astendussõnu käsitlevas uurimuses esile huvitava seiga: väljaspool Soomet soome keelt õppinud kasutavad paljusid erinevaid astendussõnu, samas kui soomekeelses keskkonnas õppinud kasutavad peamiselt moeväljendeid ja nii varieeruvad nende astendussõnad vähem.

Mare Kitsnik käsitleb konditsionaali kasutust eesti B1- ja B2-taseme õppijakeele kirjalikes tekstides. Uurimistulemused näitavad, et eesti keele õppijate konditsionaali kasutamine on B2-tasemel võrreldes B1-tasemega sagedasem ja komplekssem. Samuti suureneb B2-tasemel keelekasutuse täpsus. Seega on konditsionaali kasutamine üks B-tasemeid eristav determinant.

LV alustab uut 30-aastast eluetappi ja ootab 2015. aasta fennougristikakongressi innustusel tulevastesse numbritesse senisest veelgi enamaid soome-ugri sihtkeeli käsitlevaid artikleid. Täname oma seniseid autoreid mitmekülgsete artiklite ja retsensente väärtuslike kommentaaride eest, mida oleme pingsalt arvestanud. Suur tänu majandusliku toe eest Kone sihtasutusele, Soome-Ugri Kultuuriseltsi sihtasutusele ja Eesti 
Haridus- ja Teadusministeeriumi rahastatavale riiklikule programmile “Eesti keel ja kultuurimälu II”. Peame eriti tähtsaks, et ajakiri "Lähivõrdlusi. Lähivertailuja” ilmub Eesti Rakenduslingvistika Ühingu egiidi all. Aitäh selle eest!

Tallinnas, Viinis ja Turus

Annekatrin Kaivapalu, Johanna Laakso, Kirsti Siitonen ja Katre Õim 